Bangl. J. Vet. Med. (2008). 6 (1): 13-18

\title{
DRUG SENSITIVITY PATTERN OF ESCHERICHIA COLI ISOLATED FROM SAMPLES OF DIFFERENT BIOLOGICAL AND ENVIRONMENTAL SOURCES
}

\author{
M. A Zinnah ${ }^{1}$, M. H. Haque ${ }^{1}$, M. T. $\operatorname{Islam}^{1 \& 2}$, M. T. $\operatorname{Hossain}^{1}$, M. R. Bari ${ }^{3}$, S. A. M. Babu ${ }^{4}$, M. T. Rahman ${ }^{1}$ and $^{*}$ \\ M. A. Islam ${ }^{1 *}$ \\ ${ }^{1}$ Department of Microbiology and Hygiene, ${ }^{2}$ Department of Medicine, Faculty of Veterinary Science, \\ Bangladesh Agricultural University, Mymensingh-2202, Bangladesh \\ Corresponding author’s e-mail address: alim_bau@yahoo.co.in
}

\begin{abstract}
A total of 100 different $E$. coli isolates collected from 10 different biological and environmental sources (10 isolates from each source) such as human faces, human urine, cattle, sheep, goat, chicken, duck, pigeon, drain sewage and soil were used for in-vitro drug sensitivity test in the Department of Microbiology and Hygiene, Bangladesh Agricultural University, Mymensingh during the period from January to May 2007. Ten different drugs such as Gentamicin (GM), Azithromycin (AZM), Erythromycin (E), Levofloxacin (LVX), Ciprofloxacin (CIP), Tetracycline (TE), Amoxicillin (A), Ampicillin (AP), Nalidixic acid (NA) and Metronidazole (MET) were used in this study. Sensitivity test was carried out by the Kirby-Bauer disc diffusion method as per recommendation of National Committee for Clinical Laboratory Standards and efficacy of a drug was determined by measuring the diameter of the zone of inhibition that results from diffusion of the agent in to the medium surrounding the disc. A high of $80 \%$ and $78 \%$ E. coli isolates collectively from all the selected sources were sensitive to LVX and CIP respectively, followed by GM (46\%), AZM (45\%), TE (30\%), AP (29\%), E (19\%), NA (18\%) and A (15\%). No isolate was sensitive to MET (0\%). Incase of resistance, $96 \%$ isolates were resistant to MET, followed by A (72\%), E (69\%), NA (67\%), TE (60\%), AP (59\%), AZM (33\%) and GM (32\%), CIP (8\%) and LVX (5\%). A number of isolates showed intermediate reaction to GM (22\%), AZM (22\%), LVX (15\%), NA (15\%), CIP (14\%), A(13\%), AP (12\%), E (12\%), TE $(10 \%)$ and MET (4\%). This may be an intermediate phase for the conversion of $E$. coli isolates from sensitive to resistant form. From the research it may be concluded that $E$. coli infection of different animals and birds and also of human being may be treated effectively with LVX and CIP followed by GM and AZM.
\end{abstract}

Key words: E. coli isolates, levofloxacin, ciprofloxacin, efficacy, resistance

\section{INTRODUCTION}

E. coli is a major pathogen of commercially produced poultry causing colibacillosis all over the world. In birds, it causes airsacculitis, pericarditis, septicemia, and death (Hofstad et al., 1984). It is a major cause of respiratory and septicemic diseases in broiler chicken causing mortality less than $5 \%$ and morbidity over 50\% and also affects layers resulting failure of productivity and fertility of eggs (Barens and Gross, 1997). It may cause about 28\% death in Sonali birds (Biswas et al., 2006). The prevalence of E. coli infection is higher in diarrhoeic calves about $13.71 \%$ compared to non-diarrhoeic calves about $9.1 \%$ and the overall prevalence of $E$. coli incase of colibacillosis affecting calves is $97.38 \%$ and $28 \%$ of the total death in calves occurred in first month of life and $50 \%$ of death during first week due to $E$. coli infection (Debnath et al., 1990). Colisepticemia also occurs in sheep causing mortality ranged from $1 \%$ to $5 \%$ with an age distribution of 3 to 12 weeks old (Mason and Corbould, 1981). E. coli is the most common cause of food and water-borne human diarrhea worldwide in developing countries causing 800000 deaths out of 650 million cases per year primarily in children under the age of five years (Turner et al., 2006). It also causes urinary tract infection and other complications in human. E. coli is an important zoonotic pathogen. E. coli O157:H7 is pathogenic for human but non-pathogenic in cattle and present in the feces of healthy cattle (Elder et al., 2000).

Present address: ${ }^{3}$ School of Agriculture and Rural Development, Bangladesh Open University, Gazipur-1705, ${ }^{4}$ Poultry Production Research Division, BLRI, Savar, Dhaka 
Goats, sheep, and swine can also be carriers of E. coli O157:H7. Because of the lack of an efficient commercial vaccine, the control of colibacillosis mainly relies on the use of antimicrobial drugs. However, bacteria have developed strategies for survival within the host during an infection and one of these strategies is the resistance of isolates to the antimicrobial drugs. Antibiotic resistance is a serious problem because it limits the therapeutic possibilities in the treatment of bacterial diseases in domestic animal species in general and poultry in particular (Nicole et al., 2000). According to Hussain et al., 1982, the number of multi-drug resistant E. coli are continuously increasing although various antimicrobial agents are being used.

Considering the above facts, the present research work was undertaken to determine the current status of drug sensitivity and resistance pattern of the $E$. coli isolated from 10 different sources to select the drugs of choice for therapeutic use against various infections of man and animals caused by the organism.

\section{MATERIALS AND METHODS}

\section{E. coli isolates}

Hundred isolates of $E$. coli were used in this study which were previously isolated and identified, from 10 different biological and environmental sources (10 isolates from each source) such as human feces, human urine rectal swab of cattle, sheep and goat, cloacal swab of chicken, duck and pigeon, Drain sewage and soil (Zinnah et al., 2007).

\section{Antimicrobial discs}

Commercially available antimicrobial discs (BENEX Limited, USA) were used to determine the drug sensitivity and resistance pattern of the $E$. coli isolates. A number of 10 different drugs with different disc concentration such as gentamycin (GM) $10 \mu \mathrm{g} /$ disc, azithromycin (AZM) $15 \mu \mathrm{g} /$ disc, erythromycin (E) 15 $\mu \mathrm{g} /$ disc, levofloxacin (LVX) $5 \mu \mathrm{g} /$ disc, ciprofloxacin (CIP) $5 \mu \mathrm{g} /$ disc, tetracycline (TE) $30 \mu \mathrm{g} / \mathrm{disc}$, amoxicillin (A) $10 \mu \mathrm{g} /$ disc, ampicillin (AP) $10 \mu \mathrm{g} /$ disc, nalidixic acid (NA) $30 \mu \mathrm{g} /$ disc and metronidazole (MET) $80 \mu \mathrm{g} / \mathrm{disc}$ were used in this study.

\section{Antimicrobial sensitivity test of $E$. coli isolates}

The antimicrobial sensitivity test of each isolate was carried out by the Kirby-Bauser disc diffusion method (Bauser et al., 1966) as per recommendation of National Committee for Clinical Laboratory Standards (NCCLS, 1997). This method allowed for rapid determination of invitro efficacy of a drug by measuring the diameter of the zone of inhibition that results from diffusion of the agent into the medium surrounding the disc.

The suspension of each test isolate was prepared in nutrient broth by overnight culture. By sterile syringe 0.2 $\mathrm{ml}$ of broth culture of the test isolate was poured on EMB agar and nutrient agar separately. Sterile glass spreader was used to spread the culture homogenously on the medium. Inoculated plates were allowed to dry for approximately 3-5 minutes and then the antibiotic discs were applied aseptically to the surface of the inoculated agar with the help of a sterile forceps. The plates were then inverted and incubated at $37^{\circ} \mathrm{C}$ for 24 hours.

After incubation the plates were examined and the diameter of the zone of complete inhibition was measured by millimitre scale. The zone diameters for individual antimicrobial agent were translated into sensitive, intermediate and resistant categories.

\section{RESULTS AND DISCUSSION}

The sensitivity and resistance pattern of different $E$. coli isolates to different drugs are presented in Table 1 . The current study revealed that high percentage of $E$. coli isolates from human urine were sensitive to GM (80\%) and a few percent was sensitive to LVX (40\%) and AZM (20\%) but resistant to CIP, AP, NA and other drugs used. These findings were in close agreement with Lazarevic et al. (1998) and Gulsun et al. (2005) in term of GM which was $90-100 \%$ and $72 \%$ sensitive shown by them, respectively. At the same time, the present findings were contradictory with them in terms of CIP, AP, NA which were 85\%, 35\% and 90-100\% sensitive respectively. Present findings also differed with the report of Sanchez Merino et al. (2003). They showed 77.1$81.6 \%$ sensitivity to CIP and $41.4-44 \%$ sensitivity to AP. 
Drug sensitivity pattern of Escherichia coli

In the present study, all the E. coli isolates from human feces found to be sensitive to GM (100\%), CIP (100\%) followed by LVX (90\%), TE (90\%), AP (90\%) and A (60\%) showing no marked resistance to any drug except MET (90\%) which were contradictory with the findings of Shehabi et al. (2006).

They showed that the isolates were 67\%,63\%, 32\% and 33\% resistant to AP, NA, GM and TE, respectively. Present study was also contradictory with the report of Macias et al. (2002). They showed that the resistance to TE and AP was $64.4 \%$ and $52.63 \%$, respectively.

In case of cattle high percentage of E. coli isolates were sensitive to LVX (80\%) and CIP (80\%); a few number of isolates were sensitive to AZM (30\%) and NA (30\%) and resistant to TE (80\%), AP (90\%), E (90\%), A(90\%) and MET (100\%). Whereas, Joshi et al. (1986) reported that high percentage of isolates were sensitive to TE (90.90\%) and GM (54.54\%) and resistant to AP (36.36\%) and E (27.27\%), Jordan et al. (2005) showed resistance to TE (3.6\%), A (2.2\%) and GM (0.09\%), Orden et al. (2000) showed resistance to TE (above 65\%), AP (23 - 50\%) and sensitive to GM (89-95\%) and Sawant et al. (2007) found resistance to AP (48\%) and TE $(93 \%)$.

Current study showed that high percentage of sheep isolates were highly sensitive to LVX (90\%) and CIP (90\%); a moderate number to AZM (60\%) and a few to A (40\%) and resistant to TE (80\%), AP (90\%), E (90\%), NA (90\%) and MET (100\%). E. coli isolates from goat were sensitive to all the drugs except MET; being cent percent sensitive to LVX and CIP followed by TE (90\%), AP (90\%) and NA (50\%) but resistant to E (70\%), AZM (60\%), GM (50\%), A (50\%) and MET (100\%). In both cases the findings were in partial agreement with Cid et al. (1996), who reported that isolates from lambs and kids were above $70 \%$ resistant to TE and 30-50\% resistant to AP but were highly sensitive to CIP.

Table 1. Demonstration of the sensitivity and resistance pattern of different E. coli isolates to different drugs

\begin{tabular}{|c|c|c|c|c|c|c|c|c|c|c|c|c|c|c|c|c|}
\hline \multirow{3}{*}{$\begin{array}{l}\text { Sources of E.col } \\
(\mathrm{n}=10)\end{array}$} & & \multicolumn{15}{|c|}{ Sensitivity and resistance pattern of different $E$. coli isolates to different drugs } \\
\hline & & \multicolumn{3}{|c|}{ GM } & \multicolumn{3}{|c|}{ AZM } & \multicolumn{3}{|c|}{ LVX } & \multicolumn{3}{|c|}{ TE } & \multicolumn{3}{|c|}{$\mathrm{AP}$} \\
\hline & & $\mathrm{S}$ & I & $\mathrm{R}$ & $\mathrm{S}$ & I & $\mathrm{R}$ & $\mathrm{S}$ & $\mathrm{I}$ & $\mathrm{R}$ & $\mathrm{S}$ & I & $\mathrm{R}$ & $\mathrm{S}$ & I & $\mathrm{R}$ \\
\hline $\begin{array}{l}\text { Human } \\
\text { (urine) }\end{array}$ & $\begin{array}{l}\text { No. } \\
\%\end{array}$ & $\begin{array}{l}8 \\
80\end{array}$ & $\begin{array}{l}1 \\
10\end{array}$ & $\begin{array}{l}1 \\
10\end{array}$ & $\begin{array}{l}2 \\
20\end{array}$ & $\begin{array}{l}3 \\
30\end{array}$ & $\begin{array}{l}5 \\
50\end{array}$ & $\begin{array}{l}4 \\
40\end{array}$ & $\begin{array}{l}2 \\
20\end{array}$ & $\begin{array}{l}4 \\
40\end{array}$ & $\begin{array}{l}1 \\
10\end{array}$ & $\begin{array}{l}1 \\
10\end{array}$ & $\begin{array}{l}8 \\
80\end{array}$ & $\begin{array}{l}1 \\
10\end{array}$ & $\begin{array}{l}3 \\
30\end{array}$ & $\begin{array}{l}6 \\
60\end{array}$ \\
\hline $\begin{array}{l}\text { Human } \\
\text { (feces) }\end{array}$ & $\begin{array}{l}\text { No. } \\
\%\end{array}$ & $\begin{array}{l}10 \\
100\end{array}$ & $\begin{array}{l}0 \\
0\end{array}$ & $\begin{array}{l}0 \\
0\end{array}$ & $\begin{array}{l}8 \\
80\end{array}$ & $\begin{array}{l}2 \\
20\end{array}$ & $\begin{array}{l}0 \\
0\end{array}$ & $\begin{array}{l}9 \\
90\end{array}$ & $\begin{array}{l}1 \\
10\end{array}$ & $\begin{array}{l}0 \\
0\end{array}$ & $\begin{array}{l}9 \\
90\end{array}$ & $\begin{array}{l}1 \\
10\end{array}$ & $\begin{array}{l}0 \\
0\end{array}$ & $\begin{array}{l}9 \\
90\end{array}$ & $\begin{array}{l}1 \\
10\end{array}$ & $\begin{array}{l}0 \\
0\end{array}$ \\
\hline $\begin{array}{l}\text { Cattle } \\
\text { (rectal swab) }\end{array}$ & $\begin{array}{l}\text { No. } \\
\%\end{array}$ & $\begin{array}{l}4 \\
40\end{array}$ & $\begin{array}{l}0 \\
0\end{array}$ & $\begin{array}{l}6 \\
60\end{array}$ & $\begin{array}{l}3 \\
30\end{array}$ & $\begin{array}{l}2 \\
20\end{array}$ & $\begin{array}{l}5 \\
50\end{array}$ & $\begin{array}{l}8 \\
80\end{array}$ & $\begin{array}{l}2 \\
20\end{array}$ & $\begin{array}{l}0 \\
0\end{array}$ & $\begin{array}{l}2 \\
20\end{array}$ & $\begin{array}{l}0 \\
0\end{array}$ & $\begin{array}{l}8 \\
80\end{array}$ & $\begin{array}{l}1 \\
10\end{array}$ & $\begin{array}{l}0 \\
0\end{array}$ & $\begin{array}{l}9 \\
90\end{array}$ \\
\hline $\begin{array}{l}\text { Sheep } \\
\text { (rectal swab) }\end{array}$ & $\begin{array}{l}\text { No. } \\
\%\end{array}$ & $\begin{array}{l}3 \\
30\end{array}$ & $\begin{array}{l}1 \\
10\end{array}$ & $\begin{array}{l}6 \\
60\end{array}$ & $\begin{array}{l}6 \\
60\end{array}$ & $\begin{array}{l}1 \\
10\end{array}$ & $\begin{array}{l}3 \\
30\end{array}$ & $\begin{array}{l}9 \\
90\end{array}$ & $\begin{array}{l}1 \\
10\end{array}$ & $\begin{array}{l}0 \\
0\end{array}$ & $\begin{array}{l}1 \\
10\end{array}$ & $\begin{array}{l}1 \\
10\end{array}$ & $\begin{array}{l}8 \\
80\end{array}$ & $\begin{array}{l}0 \\
0\end{array}$ & $\begin{array}{l}1 \\
10\end{array}$ & $\begin{array}{l}9 \\
90\end{array}$ \\
\hline $\begin{array}{l}\text { Goat } \\
\text { (rectal swab) }\end{array}$ & $\begin{array}{l}\text { No. } \\
\%\end{array}$ & $\begin{array}{l}4 \\
40\end{array}$ & $\begin{array}{l}1 \\
10\end{array}$ & $\begin{array}{l}5 \\
50\end{array}$ & $\begin{array}{l}3 \\
30\end{array}$ & $\begin{array}{l}1 \\
10\end{array}$ & $\begin{array}{l}6 \\
60\end{array}$ & $\begin{array}{l}10 \\
100\end{array}$ & $\begin{array}{l}0 \\
0\end{array}$ & $\begin{array}{l}0 \\
0\end{array}$ & $\begin{array}{l}9 \\
90\end{array}$ & $\begin{array}{l}1 \\
10\end{array}$ & $\begin{array}{l}0 \\
0\end{array}$ & $\begin{array}{l}9 \\
90\end{array}$ & $\begin{array}{l}1 \\
10\end{array}$ & $\begin{array}{l}0 \\
0\end{array}$ \\
\hline $\begin{array}{l}\text { Chicken } \\
\text { (cloacal swab) }\end{array}$ & $\begin{array}{l}\text { No. } \\
\%\end{array}$ & $\begin{array}{l}3 \\
30\end{array}$ & $\begin{array}{l}1 \\
10\end{array}$ & $\begin{array}{l}6 \\
60\end{array}$ & $\begin{array}{l}0 \\
0\end{array}$ & $\begin{array}{l}2 \\
20\end{array}$ & $\begin{array}{l}8 \\
80\end{array}$ & $\begin{array}{l}8 \\
80\end{array}$ & $\begin{array}{l}2 \\
20\end{array}$ & $\begin{array}{l}0 \\
0\end{array}$ & $\begin{array}{l}0 \\
0\end{array}$ & $\begin{array}{l}2 \\
20\end{array}$ & $\begin{array}{l}8 \\
80\end{array}$ & $\begin{array}{l}0 \\
0\end{array}$ & $\begin{array}{l}1 \\
10\end{array}$ & $\begin{array}{l}9 \\
90\end{array}$ \\
\hline $\begin{array}{l}\text { Duck } \\
\text { (cloacal swab) }\end{array}$ & $\begin{array}{l}\text { No. } \\
\%\end{array}$ & $\begin{array}{l}2 \\
20\end{array}$ & $\begin{array}{l}6 \\
60\end{array}$ & $\begin{array}{l}2 \\
20\end{array}$ & $\begin{array}{l}5 \\
50\end{array}$ & $\begin{array}{l}3 \\
30\end{array}$ & $\begin{array}{l}2 \\
20\end{array}$ & $\begin{array}{l}7 \\
70\end{array}$ & $\begin{array}{l}3 \\
30\end{array}$ & $\begin{array}{l}0 \\
0\end{array}$ & $\begin{array}{l}2 \\
20\end{array}$ & $\begin{array}{l}1 \\
10\end{array}$ & $\begin{array}{l}7 \\
70\end{array}$ & $\begin{array}{l}0 \\
0\end{array}$ & $\begin{array}{l}1 \\
10\end{array}$ & $\begin{array}{l}9 \\
90\end{array}$ \\
\hline $\begin{array}{l}\text { Pigeon } \\
\text { (cloacal swab) }\end{array}$ & $\begin{array}{l}\text { No. } \\
\%\end{array}$ & $\begin{array}{l}6 \\
60\end{array}$ & $\begin{array}{l}1 \\
10\end{array}$ & $\begin{array}{l}3 \\
30\end{array}$ & $\begin{array}{l}5 \\
50\end{array}$ & $\begin{array}{l}3 \\
30\end{array}$ & $\begin{array}{l}2 \\
20\end{array}$ & $\begin{array}{l}9 \\
90\end{array}$ & $\begin{array}{l}1 \\
10\end{array}$ & $\begin{array}{l}0 \\
0\end{array}$ & $\begin{array}{l}0 \\
0\end{array}$ & $\begin{array}{l}2 \\
20\end{array}$ & $\begin{array}{l}8 \\
80\end{array}$ & $\begin{array}{l}0 \\
0\end{array}$ & $\begin{array}{l}3 \\
30\end{array}$ & $\begin{array}{l}7 \\
70\end{array}$ \\
\hline Drain sewage & $\begin{array}{l}\text { No. } \\
\%\end{array}$ & $\begin{array}{l}2 \\
20\end{array}$ & $\begin{array}{l}6 \\
60\end{array}$ & $\begin{array}{l}2 \\
20\end{array}$ & $\begin{array}{l}7 \\
70\end{array}$ & $\begin{array}{l}2 \\
20\end{array}$ & $\begin{array}{l}1 \\
10\end{array}$ & $\begin{array}{l}10 \\
100\end{array}$ & $\begin{array}{l}0 \\
0\end{array}$ & $\begin{array}{l}0 \\
0\end{array}$ & $\begin{array}{l}4 \\
40\end{array}$ & $\begin{array}{l}0 \\
0\end{array}$ & $\begin{array}{l}6 \\
60\end{array}$ & $\begin{array}{l}9 \\
90\end{array}$ & $\begin{array}{l}1 \\
10\end{array}$ & $\begin{array}{l}0 \\
0\end{array}$ \\
\hline Soil & $\begin{array}{l}\text { No. } \\
\%\end{array}$ & $\begin{array}{l}4 \\
40\end{array}$ & $\begin{array}{l}5 \\
50\end{array}$ & $\begin{array}{l}1 \\
10\end{array}$ & $\begin{array}{l}6 \\
60\end{array}$ & $\begin{array}{l}3 \\
30\end{array}$ & $\begin{array}{l}1 \\
10\end{array}$ & $\begin{array}{l}6 \\
60\end{array}$ & $\begin{array}{l}3 \\
30\end{array}$ & $\begin{array}{l}1 \\
10\end{array}$ & $\begin{array}{l}2 \\
20\end{array}$ & $\begin{array}{l}1 \\
10\end{array}$ & $\begin{array}{l}7 \\
70\end{array}$ & $\begin{array}{l}0 \\
0\end{array}$ & $\begin{array}{l}0 \\
0\end{array}$ & $\begin{array}{l}10 \\
10\end{array}$ \\
\hline
\end{tabular}

Legends: GM = Gentamicin; AZM = Azithromycin; LVX = Levofloxacin; TE = Tetracycline; AP = Ampicillin; $\mathrm{S}$ = sensitive; $\mathrm{I}=$ intermediate; $\mathrm{R}=$ resistant; $\mathrm{n}=$ number of isolates of $E$. coli from each source. 
Table 1. Demonstration of the sensitivity and resistance pattern of different $E$. coli isolates to different drugs (continued)

\begin{tabular}{|c|c|c|c|c|c|c|c|c|c|c|c|c|c|c|c|c|}
\hline \multirow{3}{*}{\multicolumn{2}{|c|}{$\begin{array}{l}\text { Sources of E.coli } \\
(\mathrm{n}=10)\end{array}$}} & \multicolumn{15}{|c|}{ Sensitivity and resistance pattern of different $E$. coli isolates to different drugs } \\
\hline & & \multicolumn{3}{|c|}{ CIP } & \multicolumn{3}{|c|}{$\mathrm{E}$} & \multicolumn{3}{|c|}{ A } & \multicolumn{3}{|c|}{ NA } & \multicolumn{3}{|c|}{ MET } \\
\hline & & $\mathrm{S}$ & I & $\mathrm{R}$ & $\mathrm{S}$ & I & $\mathrm{R}$ & $\mathrm{S}$ & I & $\mathrm{R}$ & $\mathrm{S}$ & I & $\mathrm{R}$ & $\mathrm{S}$ & I & $\mathrm{R}$ \\
\hline \multirow{2}{*}{$\begin{array}{l}\text { Human } \\
\text { (urine) }\end{array}$} & No. & 2 & 2 & 6 & 0 & 0 & 10 & 0 & 0 & 10 & 0 & 0 & 10 & 0 & 0 & 10 \\
\hline & $\%$ & 20 & 20 & 60 & 0 & 0 & 100 & 0 & 0 & 100 & 0 & 0 & 100 & 0 & 0 & 100 \\
\hline \multirow{2}{*}{$\begin{array}{l}\text { Human } \\
\text { (feces) }\end{array}$} & No. & 10 & 0 & 0 & 6 & 2 & 2 & 4 & 2 & 4 & 3 & 2 & 5 & 0 & 4 & 6 \\
\hline & $\%$ & 100 & 0 & 0 & 60 & 20 & 20 & 40 & 20 & 40 & 30 & 20 & 50 & 0 & 40 & 60 \\
\hline \multirow{2}{*}{$\begin{array}{l}\text { Cattle } \\
\text { (rectal swab) }\end{array}$} & No. & 8 & 2 & 0 & 1 & 0 & 9 & 0 & 2 & 8 & 3 & 1 & 6 & 0 & 0 & 10 \\
\hline & $\%$ & 80 & 20 & 0 & 10 & 0 & 90 & 0 & 20 & 80 & 30 & 10 & 60 & 0 & 0 & 100 \\
\hline \multirow{2}{*}{$\begin{array}{l}\text { Sheep } \\
\text { (rectal swab) }\end{array}$} & No. & 9 & 1 & 0 & 0 & 1 & 9 & 4 & 2 & 4 & 0 & 1 & 9 & 0 & 0 & 10 \\
\hline & $\%$ & 90 & 10 & 0 & 0 & 10 & 90 & 40 & 20 & 40 & 0 & 10 & 90 & 0 & 0 & 100 \\
\hline \multirow{2}{*}{$\begin{array}{l}\text { Goat } \\
\text { (rectal swab) }\end{array}$} & No. & 10 & 0 & 0 & 2 & 1 & 7 & 4 & 1 & 5 & 5 & 2 & 3 & 0 & 0 & 10 \\
\hline & $\%$ & 100 & 0 & 0 & 20 & 10 & 70 & 40 & 10 & 50 & 50 & 20 & 30 & 0 & 0 & 100 \\
\hline \multirow{2}{*}{$\begin{array}{l}\text { Chicken } \\
\text { (cloacal swab) }\end{array}$} & No. & 9 & 1 & 0 & 0 & 2 & 8 & 0 & 1 & 9 & 1 & 2 & 7 & 0 & 0 & 10 \\
\hline & $\%$ & 90 & 10 & 0 & 0 & 20 & 80 & 0 & 10 & 90 & 10 & 20 & 70 & 0 & 0 & 100 \\
\hline \multirow{2}{*}{$\begin{array}{l}\text { Duck } \\
\text { (cloacal swab) }\end{array}$} & No. & 6 & 2 & 2 & 0 & 1 & 9 & 0 & 1 & 9 & 0 & 1 & 9 & 0 & 0 & 10 \\
\hline & $\%$ & 60 & 20 & 20 & 0 & 10 & 90 & 0 & 10 & 90 & 0 & 10 & 90 & 0 & 0 & 100 \\
\hline \multirow{2}{*}{$\begin{array}{l}\text { Pigeon } \\
\text { (cloacal swab) }\end{array}$} & No. & 8 & 2 & 0 & 0 & 1 & 9 & 0 & 2 & 8 & 0 & 1 & 9 & 0 & 0 & 10 \\
\hline & $\%$ & 80 & 20 & 0 & 0 & 10 & 90 & 0 & 20 & 80 & 0 & 10 & 90 & 0 & 0 & 100 \\
\hline \multirow[t]{2}{*}{ Drain sewage } & No. & 10 & 0 & 0 & 4 & 1 & 5 & 3 & 1 & 6 & 6 & 3 & 1 & 0 & 0 & 10 \\
\hline & $\%$ & 100 & 0 & 0 & 40 & 10 & 50 & 30 & 10 & 60 & 60 & 30 & 10 & 0 & 0 & 100 \\
\hline \multirow[t]{2}{*}{ Soil } & No. & 6 & 4 & 0 & 6 & 3 & 1 & 0 & 1 & 9 & 0 & 2 & 8 & 0 & 0 & 10 \\
\hline & $\%$ & 60 & 40 & 0 & 60 & 30 & 10 & 0 & 10 & 90 & 0 & 20 & 80 & 0 & 0 & 100 \\
\hline
\end{tabular}

Legends: CIP = Ciprofloxacin; E = Erythromycin; A = Amoxicillin; NA = Nalidixic Acid; MET = Metronidazole; $\mathrm{S}=$ sensitive; $\mathrm{I}=$ intermediate; $\mathrm{R}$ = resistant; $\mathrm{n}=$ number of isolates of $E$. coli from each source

In case of chicken a very high percentage of E. coli isolates were sensitive to CIP (90\%) and LVX (80\%) but resistant to other drugs such as GM (60\%), NA (70\%), AZM (80\%), TE (80\%), E (80\%), AP (90\%), A (90\%) and MET (100\%) which were in partial agreement with the findings of Islam et al. (2004) who found $50 \%$ of the E. coli isolates were resistant to AP, $100 \%$ to NA and high percentage of isolates were sensitive to CIP. Present findings were also in partial agreement with Nazir et al. (2005). They found that the organisms were $100 \%$ resistant to NA, $92.30 \%$ to $\mathrm{E}$ and $61.53 \%$ to AP while $79.92 \%$ isolates were sensitive to CIP but Yang et al. (2004) showed that high percentage of isolates displayed resistance to NA (100\%), TE (98\%), AP (79\%), CIP (79\%), and LVX (64\%).

Most of the E. coli isolates from duck were found to be sensitive to LVX (70\%) followed by CIP (60\%) and AZM (50\%) but resistant to TE (70\%) AP (90\%), E (90\%), A (90\%), NA (90\%) and MET (100\%). However, these findings could not be compared due to unavailability of relevant literature.

A good number of pigeon isolates were sensitive to LVX (90\%) and CIP (80\%) followed by GM (60\%) and AZM (50\%) but highly resistant to other drugs such as MET (100\%), NA (90\%), TE (80\%), A (80\%), E (90\%), and AP (70\%). On the other hand, Sato et al. (1978) found 23\% TE resistant E. coli from domestic pigeons and $21.2 \%$ from feral pigeons. Sensitivity and resistant pattern to other drugs could not be compared due to lack of relevant literature. 
The present study also revealed that isolates from drain sewage were sensitive to a good number of drugs. All the isolates were sensitive to LVX (100\%) and CIP (100\%) followed by AP (90\%), AZM (70\%) and NA (60\%) but resistant to MET (100\%), TE (60\%) and E (50\%). On the other hand, moderate number of isolates from soil were sensitive to AZM (60\%), LVX (60\%) and E (60\%) and CIP (60\%) and a few to GM (40\%) but resistant to MET (100\%), AP (100\%), NA (90\%), A (90\%) and TE (70\%). These findings also could not be compared because of unavailability of relevant literature.

Sensitivity of the E. coli isolates from different sources to a particular drug was variable. Isolates irrespective of sources showed sensitivity to GM ranging from 20-100\%, to AZM ranging from $0-80 \%$, to LVX ranging from $40-100 \%$, to TE ranging from $0-90 \%$, to AP ranging from $0-90 \%$, to CIP ranging from $20-100 \%$, to E ranging from $0-60 \%$, to A ranging from $0-40 \%$, to NA $0-60 \%$ and to MET $0 \%$. High percentage E. coli isolates collectively from all the selected sources were sensitive to LVX (80\%) and CIP (78\%) followed by GM (46\%) and AZM (45\%); low percentage of isolates were sensitive to TE (30\%), AP (29\%), E (19\%), NA (18\%) and A (15\%). No isolate showed sensitivity to MET (0\%).

Resistance of the $E$. coli isolates from different sources to a particular drug was also variable. Isolates irrespective of sources showed resistance to GM ranging from 0-60\%, to AZM ranging from 0-80\%, to LVX ranging from $0-40 \%$, to TE ranging from $0-80 \%$, to AP ranging from $0-100 \%$, to CIP ranging from $0-60 \%$, to $\mathrm{E}$ ranging from $10-100 \%$, to A ranging from $40-100 \%$, to NA $10-100 \%$ and to MET $60-100 \%$. High percentage of E. coli isolates collectively from all the selected sources were resistant to MET (96\%) followed by A (72\%), E (69\%), NA (67\%), TE (60\%), AP (59\%), AZM (33\%) and GM (32\%). A very low percentage of isolates were resistant to CIP (8\%) and LVX (5\%).

The current study also revealed that a number of $E$. coli isolates irrespective of sources showed intermediate reaction to GM (22\%), AZM (22\%), LVX (15\%), NA (15\%), CIP (14\%), A(13\%), AP (12\%), E (12\%), TE $(10 \%)$ and MET (4\%). This may be an intermediate phase for the conversion of $E$. coli isolates from sensitive to resistant form.

In Bangladesh there is clear evidence of abuse of antibiotics due to which emergence of multi-drug resistant $E$. coli are continuously increasing day-by-day as stated by Hussain et al. (1982). Based on the present study, it may be concluded that LVX and CIP will be the first drugs of choice and GM and AZM will be the second drugs choice to resist the infections caused by E. coli in human, cattle, sheep, goat, chicken, duck and pigeon.

\section{REFERENCES}

1. Barens JH and Gross WB (1997). Colibacillosis, IN: Diseases of poultry. Edited by: Calnec BW, $9^{\text {th }}$ edn., Iowa University Press, Iowa, USA.

2. Bauser AW, Kirby WMM, Sheris JC and Truck M (1966). Antibiotic susceptibility testing by a standardized single disc method. American Journal of Clinical Pathology 145: 225-230.

3. Biswas PK, Uddin GM, Barua H, Roy K, Biswas D, Ahad A and Debnath N C (2006). Causes of loss of Sonali chickens on smallholder households in Bangladesh. Preventive Veterinary Medicine 76(3-4): 185-195.

4. Cid D, Piriz S, Ruiz-Santa-Quiteria JA, Valle J, Vadillo S and De La Fuente R (1996). In vitro susceptibility of Escherichia coli strains isolated from diarrhoeic lambs and goat kids to 14 antimicrobial agents. Journal of Veterinary Pharmacology Therapeutics 19(5): 397-401.

5. Debnath NC, Sil BK, Selim SA, Prodhan MAM and Howlader MR (1990). A respective study of calf morbidity and mortality in small holder traditional farms in Bangladesh. Preventive Veterinary Medicine 9: 1-7.

6. Elder RO, Keen JF and Siragusa GR (2000). Correlation of enterohemorrhagic Escherichia coli O157 prevalence in feces, hides, and carcasses of beef cattle during processing. Proceedings of National Academy of Science 97: 29993003 .

7. Gulsun S, Oguzoglu N, Inan A and Ceran N (2005). The virulence factors and antibiotic sensitivities of Escherichia coli isolated from recurrent urinary tract infections. Saudi Medical Journal 26(11): 1755-1758.

8. Hofstad MS, John BH, Calnek BW, Reid WN and Yoder JHW (1984). Diseases of poultry. $8^{\text {th }}$ edn., Panima Education Book Agreny, New Delhi, India, pp. 65-123.

9. Hussain MM, Glass RJ and Khan MR (1982). Antibiotic used in a rural community in Bangladesh. International Journal of Epidemiology 11: 402-405.

10. Islam MT, Islam MA, Samad MA and Kabir SML (2004). Characterization and antibiogram of Escherichia coli associated with mortality in broilers and duckling in Bangladesh. Bangladesh Journal of Veterinary Medicine 2: 0914. 
11. Jordan D. Morris SG, Gill P, Andersen LM, Chowdhury A, Stevenson AE and Spence SA (2005). Mass screening for antimicrobial resistant Escherichia coli in dairy cows in northern New South Wales. Australian Veterinary Journal 83(11): 688-694.

12. Joshi BP, Pociecha JZ and Yousif YA (1986). Drug sensitivity pattern of organisms isolated from calf colibacillosis in Mosul (Iraq). Indian Veterinary Journal 63: 783-784.

13. Lazarevic G, Petreska D and Pavlovic S (1998). Antibiotic sensitivity of bacteria isolated from the urine of children with urinary tract infections from 1986 to 1995. Srp Arh Celok Lek 126(11-12): 423-429.

14. Macias AE, Herrera LE, Munoz JM and Medina H (2002). Antibiotic-resistant fecal Escherichia coli in healthy children. Induced by the use of antibiotics. Revista de Investigacion Clinica 54(2): 108-112.

15. Mason RW and Corbould A (1981). Colisepticaemia of lambs. Australian Veterinary Journal 57(10): 458-460.

16. National Committee for Clinical Laboratory Standards. Methods for dilution antimicrobial susceptibility tests for bacteria that grow aerobically, $3^{\text {rd }}$ edn., approved standard. NCCLS, Pennsylvania. Document M7-A3. 1997.

17. Nazir KHMNH, Rahman MB, Nasiruddin KM, Akhtar F, Khan MRF and Islam MS (2005). Antibiotic sensitivity of Escherichia coli isolated from water and its relation with plasmid profile analysis. Pakistan Journal of Biological Science 8: 1610-1613.

18. Nicole L, Musangu N, Gabriel B and Joseph R (2000). Retrospective study on Escherichia coli infection in broiler subjected to postmortem examination and antibiotic resistance of isolates in Trinidad. Avian Diseases 44: 155-160.

19. Orden JA, Ruiz-Santa-Quiteria JA, García S, Cid D and De La Fuente R (2000). In vitro susceptibility of Escherichia coli strains isolated from diarrhoeic dairy calves to 15 antimicrobial agents. Joural of Veterinary Public Health. 47(5): 329-335.

20. Sanchez Merino JM, Guillan Maquieira C, Fuster Foz C, Madrid Garcia FJ, Jimenez Rodriguez M and Garcia Alonso J (2003). Microbial sensitivity of Escherichia coli in community-acquired urinary tract infections. Actas Urol Esp 27(10): 783-787.

21. Sato G, Oka C, Asagi M and Ishiguro N (1978). Detection of conjugative R plasmids conferring chloramphenicol resistance in Escherichia coli isolated from domestic and feral pigeons and crows. Zentralbl Bakteriol 241(4): 407417.

22. Sawant AA, Hegde NV, Straley BA, Donaldson SC, Love BC, Knabel SJ and Jayarao BM (2007). Antimicrobialresistant enteric bacteria from dairy cattle. Applied Environmental Microbiology 73(1): 156-163.

23. Shehabi AA, Odeh JF and Fayyad M (2006). Characterization of antimicrobial resistance and class 1 integrons found in Escherichia coli isolates from human stools and drinking water sources in Jordan. Journal of Chemotherapy 18(5): 468-472.

24. Turner SM, Scott-Tucker A, Cooper LM and Henderson IR (2006). Weapons of mass destruction: virulence factors of the global killer enterotoxigenic Escherichia coli. FEMS Microbiology Letters 263(1): 10-20.

25. Yang H, Chen S, White DG, Zhao S, McDermott P, Walker R and Meng J ( 2004). Characterization of multipleantimicrobial-resistant Escherichia coli isolates from diseased chickens and swine in China. Journal of Clinical Microbiolgy 42(8): 3483-3489.

26. Zinnah MA, Bari MR, Islam MT, Hossain MT, Rahman MT, Haque MH, Babu SAM, Ruma RP and Islam MA (2007). Characterization of Escherichia coli isolated from samples of different biological and environmental sources. Bangladesh Journal of Veterinary Medicine 5 (1\&2): 25-32. 